\title{
HUBUNGAN ANTARA KEPEMIMPINAN MANAJERIAL KEPALA SEKOLAH DENGAN KINERJA GURU SMA NEGERI KABUPATEN BULUKUMBA
}

\author{
Kaharuddin \\ Dinas Pendidikan Kabupaten Bulukumba \\ muhammadsyahrulkahar@gmail.com
}

Diterima:21 Januari 2017. Disetujui:20 Februari 2017. Dipublikasikan:1 Maret 2017

\begin{abstract}
ABSTRAK
Penelitian ini bertujuan untuk mengetahui penguruh kepemimimpian manajerial kepala sekolah terhadap kinerja guru SMA Negeri Kabupaten Bulukumba. Jenis penelitian ini adalah survei, menggunakan instrumen berupa kuesioner yang dikembangkan dalam bentuk model skala likert. Data tersebut dianalisis dengan menggunakan analisis statistik deskriptif dan inferensial.Hasil penelitian menunjukkan bahwa kepemimpinan manajerial kepala SMA Negeri Kabupaten Bulukumba berada pada kategori sedang. Kinerja guru SMA Negeri Kabupaten Bulukumba berada pada kategori cenderung kuat pada responden kepala sekolah, wakil kepala sekolah dan komite sekolah sedangkan kategori kuat pada responden siswa. Kepemimipinan manajerial kepala sekolah mempunyai hubungan yang signifikan dan berada pada kategori kuat dengan kinerja guru SMA Negeri Kabupaten Bulukumba.

Kata kunci: Kepemimpinan, Manajerial Kepala Sekolah, Kinerja Guru

\section{PENDAHULUAN}

Peningkatan kualitas sumber daya manusia (SDM) merupakan kebutuhan mendesak yang perlu diprioritaskan oleh Pemerintah dalam menghadapi era globalisasi dimana perkembangan teknologi dan informasi yang begitu cepat. Harus diakui bahwa masalah yang dihadapi bidang pendidikan di Indonesia pada hakekatnya adalah masalah kinarja manejemen. Kinerja manejemen ini ditengarai sebagai salah satu faktor yang potensial dalam mempengaruhi dunia pendidikan, yang meliputi berbagai sumber daya terkait dengan pendidikan yang berdampak pada mutu luaran yang dihasilkan. Menejemen yang profesional lebih menjanjikan untuk mendapatkan hasil yang baik dibandingkan dengan

yang kurang profesional. Kwalitas pendidik dan kinerja organisasi hendaknya berada pada tingkatan yang terbaik untuk memberi jaminan akan pencapaian hasil yang lebih baik.

Peran pendidik atau guru dalam penyelenggaraan pendidikan mempunyai posisi sentral dan strategis, khususnya dalam menjadikan tujuan pendidikan nasional sebagai prioritas utama yang harus dijangkau secara optimal. Hal ini dapat dipahami karena kelancaran penyelenggaraan tugas-tugas kependidikan sangat tergantung pada kemampuan guru baik kualitas maupun kuantitas selain tergantung pula pada partisipasi seluruh masyarakat.

Berbagai usaha telah dilakukan untuk meningkatkan mutu pendidikan
\end{abstract}


antara lain melalui berbagai pelatihan untuk meningkatkan kualitas guru, pengadaan buku dan alat pelajaran, perbaikan sarana dan prasarana pendidikan lainnya. Dengan demikian upaya peningkatan kualitas pendidikan melibatkan pemerintah pusat, pemerintah daerah dan kepala sekolah sebagai pelaksana pendidikan di sekolah. Maka keberhasilan tujuan pendidikan sangat dipengaruhi oleh kepemimpinan dan kemampuan manajerial kepala sekolah dalam membina guru dan mengelola sekolah sebagai lembaga pendidikan.

Menurut Moerdjiarto (2002) dalam pengelolaan sekolah, peran kepala sekolah sangat menonjol, bukti bahwa peran tersebut sangat kuat, keberadaan kepala sekolah yang baik, sangat besar sumbangannya terhadap sekolah unggul. Tidak pernah ada sekolah unggul, yang memiliki kepala sekolah yang bermutu rendah. Sedangkan Mulyasa (2004) mengatakan kepala sekolah harus memiliki strategi yang tepat untuk meningkatkan profesionalisme tenaga kependidikan di sekolahnya, menciptakan iklim sekolah yang kondusif, dan memberikan nasehat kepada warga sekolah. Berdasarkan penelitian yang pernah dilakukan Ali dkk (2015) menunjukkan bahwa kepala sekolah menerapkan gaya kepemimpinan instruktif(telling) dalam meningkatkan kedisiplinan,gaya kepemimpinan konsultatif (selling) dalam meningkatkan motivasi kerja guru, gaya kepemimpinan delegatif (delegating) dalam meningkatkan tanggung jawab guru.

Salah satu tanggung jawab kepala sekolah adalah sebagai manajer pendidikan tingkat sekolah dan ujung tombak utama dalam mengelola pendidikan level sekolah. Tanggung jawab tersebut tentunya bermuara pada pembinaan kinerja guru di sekolah. Setiap guru tidak selamanya bebas dari kelemahan dan kekurangan dalam menjalankan tugasnya. Menghadapi kondisi demikian, peranan pembinaan (kepemimpinan) kepala sekolah sangat menentukan dalam mengindentifikasi berbagai kelemahan guru tersebut, sebab guru merupakan komponen manusiawi yang sangat penting yang harus mendapatkan perhatian setiap saat dari kepala sekolah selaku leader (pembina), misalnya dapat kita lirik dari kesenjangan pengetahuan, keterampilan dan sikap guru harus segera dicarikan pemecahannya, sehingga tidak menimbulkan pengaruh yang negatif terhadap perkembangan pendidikan di sekolah.

Banyaknya guru yang kurang berkembang dalam menjalankan tugasnya disebabkan karena kepala sekolah dalam menjalankan tugas manajerialnya kurang inisiatif dan kreatif dalam mengambil langkahlangkah kebijakan untuk mengadakan pembinaan kepada guru dan pembinaan yang dilakukan hanya seperlunya saja. Jamali \& Prasojo (2013) mengungkapkan bahwa kompetensi manajerial kepala sekolah dan motivasi berprestasi guru apabila ditingkatkan kualitasnya maka akan berkontribusi positif terhadap peningkatan prestasi belajar siswa.

Pendidikan nasional dewasa ini dalam pengamatan para pakar pendidikan berada dalam keadaan yang terpuruk yang memerlukan paradigma baru, dengan sendirinya juga memerlukan reformasi, yaitu 
membangun masyarakat Indonesia baru (Tilaar, 2002). Pengelolaan sumber daya manusia merupakan titik sentral dalam manajemen modern. Hal ini didasari oleh asumsi bahwa manusia merupakan penentu bagi tercapainya tujuan organisasi.

Sekolah sebagai satu unit organisasi pendidikan formal merupakan wadah kerja sekelompok orang (kepala sekolah, guru-guru, staf, dan siswa) untuk mencapai tujuan yang diinginkan. Kinerja guru sangat dipengaruhi oleh berbagai faktor. Di satu pihak, ada kemungkinan kinerja guru-guru berhasil dalam pekerjaannya karena ia memiliki kemampuan dan ketrampilan untuk itu. Di pihak lain, tingkat kinerja guru dapat pula dipengaruhi oleh hubungan interaktif berbagai dalam kerja sepertinya alat-alat, metode atau cara kerja, hubungan dengan rekan sekerja, dan lain-lain. Dalam proses pengelolaan sekolah, faktor strategi manajemen konflik oleh kepala sekolah, iklim sekolah, insentif guru, dan motivasi berprestasi guru menjadi penting dan sangat dibutuhkan.

Membina kemampuan kerja guru dalam proses belajar mengajar berarti melestarikan pcndidikan di sekolah dan sekaligus meningkatkan dedikasi kinerja para guru. Rendahnya disiplin kerja para guru, semangat dan kegairahan serta lemahnya dedikasi adalah merupakan wujud ketidakpuasan guru terhadap tugas pembinaan dari Kepala Sekolah terhadap guru tersebut.

Dengan demikian kinerja guru dalam mengajar kurang terangsang dalam upaya pngembangan misi sekolah. Dalam rangka meningkatkan mutu pendidikan merupakan hal sulit untuk dicapai karena pengembangan misi sekolah sebagian tergantung pada kemampuan guru dalam melaksanakan tugas belajar mengajar tersebut yang tentunya hal tersebut ditentukan oleh efektivitas kepemimpinan dan pembinaan yang dilakukan oleh kepala sekolah itu sendiri. Oleh karena itu gayakepemimpinan kepala sekolah dapat membantu memperbaiki kinerja guru dalam melaksanakan tugas dan tangggung jawabnya disekolah. Sekolah menengah atas negeri kabupaten Bulukumba merupakan merupakan tantangan bagi pemerintah daerah untuk mempertahankan atau meningkatkan kualitas mutu pendidikan. Jika dikaitkan dengan kinerja guru sekolah menengah atas negeri kabupaten Bulukumba, maka perlu adanya kajian kepemimpinan manajerial kepala sekolah karena baik buruknya kinerja guru dalam melaksanakan tugasnya di sekolah pada dasarnya bertumpu pada efektif-tidaknya pelaksanaan fungsi kepemimpinan kepala sekolah, sebab makin intensifnya peranan kepala sekolah dalam melaksanakan pembinaan dan kepemimpinan terhadap guru, makin berkembang pula kemampuan menjalankan tugas guru di sekolah.

\section{METODE PENELITIAN}

Jenis penelitian ini adalah penelitian survei dengan menganalisis hubungan antara kemimpinan manajerial kepala sekolah (Variabel bebas) dengan kinerja guru (variabel terikat) pada SMA Negeri Kabupaten Bulukumba. Jenis penelitian tersebut dimaksudkan untuk menentukan masalah-masalah yang dihadapi kepala sekolah dalam rangka meningkatkan kinerja guru. Penelitian 
ini dilaksanakan di wilayah Kabupaten Bulukumba Provinsi Sulawesi Selatan tepatnya di SMA Negeri 8 Bulukumba, SMA Negeri 7 Bulukumba dan SMA Negeri 2 Bulukumba.

Populasi penelitian ini adalah semua SMA Negeri Kabupaten Bulukumba yang berjumlah 12 sekolah. Sampel ditarik dengan menggunakan tehnik purposive sampling, maka dipilih tiga SMA Negeri yaitu: (1) SMA Negeri 8 Bulukumba, (2) SMA Negeri 2Bulukumba, dan (3) SMA Negeri 7 Bulukumba.Tehnik yang digunakan dalam memilih sampel yang menjadi responden dari 3 (tiga) sekolah adalah tehnik simple randam sampling dengan mengambil $95 \%$ dari populasi karena anggota populasi pada penelitian ini homogen (sugiyono, 2003).

Tabel 1. Rincian Pengambilan Sampel Penelitian

\begin{tabular}{clcc}
\hline No. Nama sekolah & $\begin{array}{c}\text { Jumlah } \\
\text { guru } \\
\text { (Populasi) }\end{array}$ & $\begin{array}{c}\text { Jumlah } \\
\text { responden } \\
\text { ( sampel) } \\
\text { (95\%) }\end{array}$ \\
\hline 1. & $\begin{array}{l}\text { SMA Negeri } 8 \\
\text { Bulukumba }\end{array}$ & 50 orang & $\begin{array}{c}46 \text { orang } \\
26 \text { orang }\end{array}$ \\
2. & $\begin{array}{l}\text { SMA Negeri } 7 \\
\text { Bulukumba }\end{array}$ & 27 orang & 28 orang \\
3. & $\begin{array}{l}\text { SMA Negeri } 2 \\
\text { Bulukumba }\end{array}$ & 29 orang \\
\hline
\end{tabular}

\section{Desain penelitian}

ju m lah

Penelitian ini ingin mengkaji dengan menggunakan pendekatan kuantitatif dengan rancangan non eksperimen, yang berarti peneliti mengkaji fakta-fakta yang telah terjadi. Dengan demikian, pada saat penelitian dilakukan para responden memiliki penghayatan, persepsi, pengalaman dan persaan serta menilai tertentu yang merefleksikan persepsi mereka terhadap semua aspek kegiatan dan keadaan di sekolahnya.

\section{Instrumen penelitian}

Dalam penelitian ini digunakan instrumen sebagai alat pengumpul data dari keseluruhan variabel penelitian yang terdiri dari :

1. Kuesioner adalah daftar pernyataan yang diberikan kepada responden untuk mengumpulkan data orang $\quad 100$ orang

kepemimpinan manajerial kepala sekolah dan kinerja guru.

2. Dokumentasi adalah alat yang dipergunakan untuk mengumpulkan data yang sehubungan dengan karakteristik responden yaitu jumlah guru, jenis kelamin dan golongan serta tingkat pendidikan.

Instrumen yang digunakan dalam penelitian ini terlebih dahulu dicobakan. Uji validasi dalam penelitian ini terutama hanya menyangkut content validity dengan langkah sebagaimana tersebut di atas dan mendapat persetujuan dari komisi pembimbing. Selanjutnya untuk menguji kesahihan butir secara empirik akan dilakukan uji coba instrumen, sehingga mampu mengumpulkan data atau informasi secara lengkap, tepat atau relevan dengan masalah dan objektif.Hasilnya 
dianalisis dengan cara menghitung koefisien korelasi antara skor item dengan skor total tes. Rumus yang digunakan untuk menghitung validasi setiap item digunakan rumus korelasi product moment.

$$
r_{x y}=\frac{\sum x y-\frac{\left(\sum x\right)\left(\sum y\right)}{N}}{\sqrt{\left[\sum x^{2}-\frac{\left(\sum x\right)^{2}}{N}\right]\left[\sum y^{2}-\frac{\left(\sum y\right)^{2}}{N}\right]}}
$$

Keterangan :

$\mathrm{r}_{\mathrm{xy}}=$ Koefisien korelasi antara variabel $\mathrm{x}$ dan $\mathrm{y}$

$\sum_{\mathrm{x}}=$ jumlah skor dalam sebaran $\mathrm{X}$

$\sum_{\mathrm{y}}=$ jumlah skor dalam sebaran $\mathrm{Y}$

$\sum_{\mathrm{xy}}=$ jumlah skor hasil kali variabel $\mathrm{X}$ dan variabel $\mathrm{Y}$

$\mathrm{N}=$ jumlah sampel

Pengujian reliabilitas instrumen dalam penelitian ini menggunakan tehnik alpa Cronbach yang dikemukakan oleh Arikunto (2002) sebagai berikut:

$R_{n}=\frac{n}{n-1}\left(1-\frac{\sum S_{i}^{2}}{S_{i}^{2}}\right)$

Keterangan:

$\mathrm{R}_{\mathrm{n}} \quad=$ reliabilitas yang dicari

$\mathrm{n} \quad=$ jumlah item

$\sum S_{i}^{2}=$ jumlah varians

$S_{i}^{2} \quad=$ varians total

Dalam penelitian ini digunakan dua buah instrumen yaitu instrumen untuk mengukur kepemimpinan manajerial kepala sekolah dan instrumen untuk mengukur kinerja guru

\section{Instrumen Kepemimpinan Manajerial Kepala Sekolah}

Instrumen kepemimpinan manajerial kepala sekolah dikembangkan dari beberapa indikator berdasarkan tinjauan pustaka dan defenisi operasional. Adapun indikator yang dimaksud adalah: 1) kemampuan merencanakan yaitu mampu menyusun rencana dan menetapkan strategi serta mampu mengefektifkan perencanaan,(2) kemampuan mengorganisasikan yaitu meliputi mampu melakukan pembagian tugas tanggung jawab, serta mampu mengelola personil, (3) kemampuan memimpin yaitu mampu mengambil keputusan dan mampu menjalin kemunikasi, dan (4) kemampuan mengendalikan yaitu mampu mengelola, pengendalian, dan mampu mengendalikan organisasi.

Instrumen penelitian yang akan digunakan terlebih dahulu diujicobakan yaitu :

\section{a. uji validasi}

Instrumen yang digunakan dalam penelitian ini perlu dilakukakn uji empirinya berdasarkan kriteria yang telah ada sebelumnya, yang telah mendapatkan suatu instrumen yang memenuhi kriteria valid. Untuk keperluan tersebut masing instrumen terlebih dahulu diuji cobakan dan dilanjutkan dengan analisis yang mengacu pada Product Moment Correlatioan dan membandingkannya dengan nilai $r$ sebesar 0,374 sebagai syarat minimal butir soal dapat dinyatakan valid (Sugiono, 2000: 106).

Hasil analisis menunjukkan bahwa dari 40 item kepemimpinan manajerial kepala sekolah yang diuji cobakan kepada 30 responden, ternyata 5 item yang dinyatakan tidak valid. Dengan demikian 35 item kepemimipinan manajerial kepala sekolah yang dinyatakan valid.

b. Uji reliabilitas instrumen 
Uji reliabilitas dilakukan untuk mengetahui sejauh mana suatu hasil pengukuran relatif konsisten pada pengujian tersebut. Reliabilitas berarti kebenaran skor-skor yang diperoleh individu yang sama walaupun dilakukakn pada waktu dan tempat yang berbeda.

Tingkat reliabilitas instrumen dianalisis dengan menggunakan formula alpa. Alasan menggunakan rumus alpa tersebut, karena skor yang diperoleh setiap butir item instrumen adalah berbentuk data interval.

Hasil analisis menunjukkan bahwa kuesioner kepemimpinan manajerial kepala sekolah, yang digunakan dalam penelitian ini masing-masing telah memiliki reliabilitas yang tinggi yaitu reliabilitas 0,961

\section{Instrumen Kinerja Guru}

Ada dua Instrumen yang digunakan untuk mendapatkan informasi tentang kinerja guru adalah pertama instrumen yang menjadi responden adalah kepala sekolah, wakil kepala sekolah dan komite sekolah dan kedua instrumen yang responden adalah siswa. Kedua instrumen tersebut diukur dengan tes model skala likert yang terdiri dari lima pilihan yang diberi bobot 5,4,3,2,1 untuk pertanyaan positip dan 1,2,3,4,5 untuk pertanyaan negatif. Instrumen penelitian yang akan digunakan terlebih dahulu diuji cobakan yaitu :

a. Uji validasi

Instrumen yang digunakan dalam penelitian ini perlu dilakukakn uji empirinya berdasarkan kriteria yang telah ada sebelumnya, yang telah mendapatkan suatu instrumen yang memenuhi kriteria valid. Untuk keperluan tersebut masing instrumen terlebih dahulu diuji cobakan dan dilanjutkan dengan analisis yang mengacu pada Product Moment Correlatioan dan membandingkannya dengan nilai $r$ sebesar 0,374 sebagai syarat minimal butir soal dapat dinyatakan valid ( Sugiono, 2000: 106).

Hasil analisis menunjukkan bahwa dari 40 item kepemimpinan manajerial kepala sekolah yang diuji cobakan kepada 30 responden, ternyata 5 item yang dinyatakan tidak valid. Dengan demikian 35 item kepemimipinan manajerial kepala sekolah yang dinyatakan valid.

\section{Tehnik Dan Prosedur Pengumpulan Data}

Dalam upaya untuk mendapatkan data yang akurat mengenai variabelvariabel yang akan dikaji dalam penelitian ini akan digunakan dua tehnik pengambilan data yaitu:

1. Penyebaran kuesioner diberikan kepada kepala sekolah, guru dan siswa. Responden diberi kebebasan untuk mengisi kuesioner.

2. Dekumentasi dilakukan terutama untuk mengetahui karakteristik responden yang meliputi jumlah guru, jenis kelamin, golongan dan tingkat pendidikan guru pada SMA Negeri yang menjadi sampel penelitian.

\section{Tehnik analisis data}

Data yang telah dikumpulkan, diolah dengan menggunakan dua macam tehnik statistik yaitu tehnik analisis statistik deskriptif dan tehnik analisis statistik infrensial. Tehnik analisis deskriptif dimaksudkan untuk mendeskripsikan gambaran kemampuan manajerial kepala sekolah dan kinerja guru dengan menggunakan rata-rata, 
standar deviasi, skor tertinggi, skor terendah, tabel frekuensi, dan persentase. Sedangkan analisis statistik infrensial dimaksudkan untuk menguji hipotesis dengan menggunakan model analisis regresi linier sederhana (Tiro, 2006).

Adapun rumus analisis regresi linier sederhana yaitu :

Keterangan :

$$
\mathrm{Y}=\beta_{\mathrm{o}}+\beta_{1} \mathrm{X}_{1}+\varepsilon
$$

$\mathrm{Y}=$ Perubah tak bebas (yang akan dimodel)

$\mathrm{X}=$ Perubah bebas (yang digunakan menaksir Y)

$\varepsilon=$ Komponen kesalahan acak

$\beta_{\mathrm{o}}=$ Penggalan $\mathrm{Y}$ dari garis regresi, yaitu titik tempat garis memotong sumbu $\mathrm{Y}$, $\beta_{1}=$ Koefisien arah garis regresi, yaitu besarnya kenaikan (penurunan) di dalam komponen deterministik $\mathrm{Y}$

Tabel 2. Distribusi Frekuensi Kepemimpinan Manajerial Kepala Sekolah

\begin{tabular}{cccc}
\hline Interval & Kategori & $\mathbf{F}$ & $\begin{array}{c}\text { Persentase } \\
(\mathbf{\%})\end{array}$ \\
\hline $131-139$ & $\begin{array}{c}\text { Sangat } \\
\text { Rendah }\end{array}$ & 2 & 22,22 \\
& Rendah & 2 & 22,22 \\
$140-149$ & Sedang & 3 & 33,33 \\
$150-159$ & Tinggi & 1 & 11,11 \\
$160-169$ & Sangat & 1 & 11,11 \\
$170-179$ & Tinggi & & \\
\hline & Jumlah & $\mathbf{9}$ & $\mathbf{1 0 0}$ \\
\hline
\end{tabular}

Sumber :Survei Tahun 2008

Berdasarkan tabel 2,diperoleh informasi bahwa kepemimpinan manajerial kepala sekolah dari 9 orang responden, yang menyatakan sangat rendah sebanyak 2 orang atau 22,22 persen, rendah sebanyak 2 orang atau 22,22 persen, sedang sebanyak 3 orang atau 33,33 persen, tinggi sebanyak 1 orang atau 11,11 persen, dan kategori sangat tinggi sebanyak 1 orang atau 11,11 persen. HASIL PENELITIAN untuk setiap satu satuan kenaikan X

\section{A. Gambaran Kepemimpinan \\ Manajerial Kepala SMA \\ NegeriKabupaten Bulukumba}

Data variabel kepemimpinan manajerial kepala sekolah di Kabupaten Bulukumba yang diwakili oleh 3 (tiga) sekolah sebagai sampel diperoleh berdasarkan kuesioner. Berdasarkan hasil analisis statistik deskriftif mengenai variabel kepemimpinan manajerial kepala sekolah di Kabupaten Bulukumba tersebut diperoleh rata-rata 151,00, median sebesar 150,00, modus sebesar 133,00 dan standar deviasi sebesar 14,17. Daftar distribusi frekuensi mengenai kepemimpinan manajerial Kepala Sekolah dapat dilihat pada Tabel 2 berikut :

\section{B. Gambaran Kinerja Guru SMA Negeri Kabupaten Bulukumba}

Data variabel kinerja guru SMA

Negeri Kabupaten Bulukumba diperoleh berdasarkan kuesioner yang diisi oleh :

1. Kepala Sekolah, Wakil Kepala Sekolah, dan Komite Sekolah.

2. Siswa - siswi SMA Negeri Kabupaten Bulukumba.

Berdasarkan data hasil isian kuesioner kepala sekolah, wakil kepala 
sekolah dan komite sekolah mengenai variabel kinerja guru SMA Negeri Kabupaten Bulukumba yang dianalisis secara statistik deskriftif diperoleh ratarata sebesar 110,00, median sebesar 109,00, modus sebesar 109,00 dan standar deviasi sebesar 2,83. Daftar Tabel 3. Distribusi Frekuensi Kinerja Guru berdasarkan Penilaian Kepala Sekolah, Wakil Kepala Sekolah dan Komite Sekolah

\begin{tabular}{|c|c|c|c|}
\hline Interval & Kategori & $\mathbf{F}$ & $\begin{array}{c}\text { Persentase } \\
(\%)\end{array}$ \\
\hline $105-106$ & $\begin{array}{l}\text { Sangat } \\
\text { Rendah }\end{array}$ & 1 & 11,11 \\
\hline $107-108$ & Rendah & 2 & 22,22 \\
\hline $109-110$ & Sedang & 2 & 22,22 \\
\hline $111-112$ & Tinggi & 2 & 22,22 \\
\hline $113-114$ & $\begin{array}{l}\text { Sangat } \\
\text { Tinggi }\end{array}$ & 2 & 22,22 \\
\hline & Jumlah & 9 & 100 \\
\hline
\end{tabular}

Berdasarkan hasil yang diperoleh pada Tabel 3 tentang kinerja guru SMA Negeri kabupaten Bulukumba yang didasarkan pada penilaian 9 (sembilan) responden yang terdiri dari kepala sekolah, wakil kepala sekolah dan komite sekolah menyatakan sangat rendah sebanyak 1 orang atau 11,11 persen, rendah sebanyak 2 orang atau 22,22 persen, sedang sebanyak 2 orang atau 22,22 persen, tinggi sebanyak 2 orang atau 22,22 persen dan sangat tinggi sebanyak 2 orang atau 22,22 persen. Dengan demikian dapat dikatakan bahwa kinerja guru berdasarkan penilaian ini cenderung berada di atas kategori rendah

Tabel 4. Distribusi Frekuensi Kinerja Guru Berdasarkan Penilaian Siswa.

\begin{tabular}{cccc}
\hline Interval & Kategori & $\mathbf{f}$ & $\begin{array}{c}\text { Persentase } \\
(\mathbf{\%})\end{array}$ \\
\hline $22-27$ & Sangat & 3 & 3.30 \\
& Rendah & & 6.60 \\
\hline
\end{tabular}

distribusi frekuensi kinerja guru SMA Negeri di Kabupaten Bulukumba berdasarkan penilaian Kepala Sekolah, Wakil Kepala Sekolah dan Komite Sekolah selengkapnya dapat dilihat pada tabel 3 berikut :
SMA Neg yang terdiri atas 91 responden terhadap variabel kinerja guru yang diolah melalui statistik deskriptif diperoleh rata-rata sebesar 42,16, median sebesar 43,00, modus sebesar 44,00 dan standar deviasi sebesar 5,50. Daftar distribusi frekuensi kinerja guru berdasarkan penilaian siswa dapat dilihat pada Tabel 4 berikut : 


\begin{tabular}{cccc}
\hline $28-33$ & Rendah & 6 & 10.98 \\
$34-39$ & Sedang & 10 & 59.34 \\
$40-45$ & Tinggi & 54 & 19.78 \\
$46-51$ & Sangat & 18 & \\
& Tinggi & \\
\hline & Jumlah & $\mathbf{9 1}$ & $\mathbf{1 0 0}$ \\
\hline \multicolumn{3}{c}{ Sumber :Survei Tahun 2008 }
\end{tabular}

Berdasarkan hasil yang diperoleh pada tabel 4 mengenai kinerja guru SMA Negeri di kabupaten Bulukumba yang didasarkan pada penilaian siswa menyatakan sangat rendah sebanyak 3 orang atau 3,30 persen, rendah sebanyak 6 orang atau 6,60 persen, sedang sebanyak 10 orang atau 10,98 persen, tinggi sebanyak 54 orang atau 59,34 persen dan sangat tinggi sebanyak 18 orang atau 19,78 persen. Dengan demikian dapat dikatakan bahwa kinerja guru berdasarkan penilaian ini berada pada kategori tinggi.

\section{Hubungan Kepemimpinan Manajerial Kepala Sekolah dengan Kinerja Guru SMA Negeri Kabupaten Bulukumba}

Besarnya hubungan antara kepemimipinan manajerial Kepala Sekolah dengan kinerja guru SMA Negeri di Kabupaten Bulukumba dapat ditinjau dari 2(dua) penilaian, yang pertama berdasarkan penilaian Kepala Sekolah, Wakil Kepala Sekolah dan Komite Sekolah, kedua berdasarkan penilaian siswa. Berdasarkan hasil analisis statistik inferensial diperoleh informasi bahwa besarnya hubungan kepemimpinan manajerial kepala sekolah dan kinerja guru SMA Negeri di Kabupaten Bulukumba berdasarkan penilaian kepala sekolah, wakil kepala sekolah dan komite sekolah adalah sebesar 0,714 atau tingkat keterkaitan antara kepemimpinan manajerial kepala sekolah dengan kinerja guru SMA Negeri di Kabupaten Bulukumba adalah sebesar 71,4 persen. Ini berarti bahwa hubungan kepemimpinan manajerial kiepala sekolah dan kinerja guru SMA Negeri Kabupaten Bulukumba adalah berada pada kategori kuat. Hal ini sesuai dengan pendapat Tiro bahwa skala nilai antara0,6 - 08 berada pada kategori kuat Variasi nilai kinerja guru yang dapat dijelaskan oleh nilai kepemimpinan manajerial Kepala Sekolah dapat dilihat berdasarkan nilai kuadrat koefisien determinasii $\left(\mathrm{R}^{2}\right)$ yaitu sebesar 0,51, yang berarti bahwa 51,0 persen variasi total nilai kinerja guru dapat dijelaskan oleh kemampuan manajerial Kepala Sekolah dan 49,0 persen dijelaskan oleh variasi lain yang tidak diteliti dalam penelitian ini.

Ditinjau berdasarkan penilaian siswa, hasil analisis statistik inferensial memberikan informasi bahwa besarnya hubungan kepemimpinan manajerial Kepala Sekolah dan kinerja guru SMA Negeri di Kabupaten Bulukumba adalah 0,743 atau tingkat keterkaitan antara kepemimpinan manajerial kepala sekolah dengan kinerja guru SMA Negeri Kabupaten Bulukumba adalah sebesar 74,3 persen. Ini berarti bahwa hubungan kepemimpinan manajerial Kepala Sekolah dan kinerja guru SMA Negeri Kabupaten Bulukumba adalah kategori kuat. Hal ini sesuai dengan 
pendapat Tiro bahwa skala nilai antara 0,6 - 08 berada pada kategori kuat

Berdasarkan penilaiaan siswa siswi ini, variasi nilai kinerja guru yang dapat dijelaskan oleh nilai kepemimpinan manajerial Kepala Sekolah dapat dilihat berdasarkan nilai kuadrat koefisien determinasi $\left(\mathrm{R}^{2}\right)$ yaitu sebesar 0,552, yang berarti bahwa 55,2 persen variasi total nilai kinerja guru dapat dijelaskan oleh kepemimpinan manajerial Kepala Sekolah dan 44,8 persen dijelaskan oleh variasi lain yang tidak diteliti dalam penelitian ini.

\section{PEMBAHASAN}

Kepemimpinan manajerial sangat berkaitan erat dengan manajemen kepemimpinan yang efektif, karena manajemen pada hakekatnya adalah masalah interaksi antar manusia, baik secara vertikal maupuan secara horizontal. Oleh sebab itu, dapat dikatakan bahwa kepemimpinan adalah inti dari manajemen. Kepemimpinan adalah perilaku di mana seseorang memotivasi orang lain untuk bekerja kearah pencapaian tujuan tertentu. Kepemimpinan yang baik seharusnya dimiliki dan diterapkan oleh semua jenjang organisasi agar bawahannya dapat bekerja dengan disiplin, bekerja dengan semangat tinggi dan bertanggung jawab dengan jujur untuk kepentingan organisasi.

Sukses tidaknya seorang kepala sekolah dalam melaksanakan tugas kepemimpinannya lebih banyak ditentukan oleh kemampuan manajerialnya dalam menggerakkan orang lain untuk bekerja secara efektif. Keterampilan menggerakkan orang lain inilah yang disebut dengan manajerial skill (Burhanuddin, 1994). Hal ini sejalan dengan pendapat yang dikemukakan oleh Siagian (1996), bahwa manajerial skill adalah keahlian menggerakkan orang lain untuk bekerja dengan baik.

Dari hasil analisis data kepemimpinan manajerial Kepala Sekolah diperoleh skor data sebesar 33,33 persen yang menunjukkan bahwa kepemimpinan manajerial kepala SMA Negeri Kabupaten Bulukumba berada pada kategori sedang, artinya kepemimpinan manajerial kepala sekolah telah terlaksana tetapi masih perlu ditingkatkan dari segi perencanaan, pengorganisasian, kepemimpinan dan pengendalian.

Rendahnya kepemimpinan manajerial kepala sekolah disebabkan karena kepala sekolah mempunyai kepemimpinan teknik, sosial dan konseptual yang masih kurang memadai. Kepala sekolah seharusnya mempunyai kepemimpinan teknis dalam menggunakan ilmu pengetahuan, metode, teknik, dan peralatan yang diperlukan untuk melaksanakan tugas tertentu yang diperoleh dari pengalaman. Kepemimpinan memasyarakatkan (mensosialisasikan) yaitu kepemimpinan yang tidak menyerah atau pantang mundur dalam bekerja dengan orang lain, yang mencakup pemahaman tentang motivasi dan penerapan kepemimpinan yang efektif. Kepemimpinan konseptual yang diterapkan untuk memahami kompleksitas oraganisasi dan penyesuaian bidang gerak dan unit kerja masing-masing ke dalam bidang operasi organisasi secara menyeluruh.

Pelaksanaan tugas kepala sekolah harus mampu memberdayakan seluruh potensi yang ada termasuk tenaga guru. 
Guru sebagai subyek pendidikan dalam proses belajar mengajar merupakan komponen sekolah yang turut bertanggung jawab terhadap kualitas belajar mengajar. Guru sebagai tenaga pendidik secara langsung berinteraksi dengan siswa dalam proses belajar mengajar. Guru sebagai sumber belajar utama bagi siswa, di samping sumber belajar lainnya. Dengan demikian guru hendaknya memiliki kinerja yang baik.

Dalam pelaksanaan tugas guru dipengaruhi beberapa faktor yang perlu diperhatikan oleh kepala sekolah dalam mengaplikasikan kemampuan manajerialnya. Menurut Gibson,et al (1997), faktor-faktor yang mempengaruhi kinerja dalam organisasi. Setiap usaha untuk mengetahui mengapa seseorang berperilaku seperti yang dilakukan selama ini di dalam organisasi memerlukan pemahaman tentang; (1) individu yang meliputi kemampuan, keterampilan mencakup mental dan fisik, latar belakang meliputi keluarga, tingkat sosial dan pengalaman, serta demografi yang mencakup umur dan jenis kelamin, (2) organisasi meliputi sumber daya, kepemimpinan, imbalan dan prosedur kerja, (3) psikologis meliputi persepsi, sikap dan kepribadian.

Sejalan yang dikemukakan oleh Arnold dan Fiedman (1996), bahwa kinerja dipengaruhi oleh persyaratan jabatan dan perilaku individu. Persyaratan jabatan merupakan criteriakriteria yang ditetapkan oleh organisasi atau lembaga tertentu, sedangkan perilaku individu terbagi dalam beberapa faktor yang secara langsung mempegaruhi kinerja seseorang, yaitu; (1) motivasi, (2) kemampuan meliputi keceradasan dan pengetahuan, persepsi, (4) kepribadian dan strukturnya. Hal ini juga didukung oleh Karang dkk (2013) bahwa terdapat hubungan yang signifikan antara kepemimpinan kepala sekolah, komptensi profesional, motivasi kerja guru terhadap kinerja guru. Hal ini sejalan dengan Wibowo dkk (2013) bahwa kompetensi manajerial kepala sekolah dengan kinerja guru dalam pengelolaan pembelajaran memiliki hubungan yang positif.

Dari hasil analisis data pada Tabel 3 mengenai kinerja guru SMA Negeri di Kabupaten Bulukumba berdasarkan penilaian kepala sekolah, wakil kepala sekolah dan komite sekolah diperoleh sebagai berikut : Kategori rendah sebanyak 2 orang dengan skor 22,22 persen, kategori sedang sebanyak 2 orang dengan skor 22,22 persen, kategori tinggi sebanyak 2 orang dengan skor 22,22 persen dan kategori sangat tinggi sebanyak 2 orang dengan skor 22,22 persen, dari hasil analisis tersebut maka termasuk kategori cenderung tinggi karena berada pada kategori rendah sampai kategori sangat tinggi. Hal ini menunujukkan bahwa kinerja guru SMA Negeri Kabupaten Bulukumba sudah baik tapi perlu lebih ditingkatkan lagi agar mutu siswa dapat lebih meningkat pula. Sedangkan berdasarkan penilaian siswa seperti yang ada pada Tabel 4 diperoleh skor sebesar 59,34 persen. Hal ini menunjukkan bahwa kinerja guru SMA Negeri Kabupaten Bulukumba berada pada kategori tinggi, yang berarti bahwa guru SMA Negeri Kabupaten Bulukumba telah memiliki kinerja yang membanggakan.

Dari kedua responden di atas menunjukkan bahwa kinerja guru SMA Negeri Kabupaten Bulukumba sudah 
kuat sehingga perlu dipelihara dan bahkan lebih ditingkatkan, supaya mutu pendidikan dapat juga meningkat terutama mutu siswa ke depan. Sedangkan menurut Gusman (2014), Kinerja guru dengan indikator tanggung jawab, motivasi kerja, dan inisiatif kerja berada dalam kategori cukup baik, Gaya kepemimpinan kepala sekolah dengan indikator kepemimpinan orientasi tugas (memberikan petunjuk kepada guru; menekankan pentingnya melaksanakan tugas dengan baik; menanamkan keyakinan bawahan dalam pelaksanaan pekerjaan). Kepemimpinan kepala sekolah berorientasi pada bawahan (memotivasi guru dalam bekrja; melibatkan guru dalam mengambil keputusan; mengembangkan hubungan kerjasama) berada pada kategori cukup baik dan terdapat hubungan yang berarti antara gaya kepemimpinan kepala sekolah dengan kinerja guru. Hal senada juga diungkapkan Frimaiyulis (2013) bahwa gaya kepemimpinan kepala sekolah memiliki hubungan dengan kinerja guru yang artinya bahwa gaya kepemimpinan merupakan salah satu faktor yang mempengaruhi kinerja guru.

Tingkat pendidikan dapat mempengaruhi kinerja guru, karena guru bertugas mentransfer ilmu pengetahuan dan keterampilan kepada siswa. Kepala sekolah harus memperhatikan prestasi kerja bawahannya dengan memberikan mereka peluang untuk melanjutkan pendidikannya ke jenjang yang lebih tinggi, serta mengikuti pelatihan atau penataran yang berhubungan dengan bidang studi yang mereka ajarkan.

Pembinaan atau pengembangan tugas kependidikan merupakan usahausaha yang mendayagunakan, mamajukan dan meningkatkan produktivitas kerja tenaga kependidikan (sekolah). Tujuan dari pembinaan itu adalah tumbuhnya kemampuan tenaga kependidikan yang meliputi pertumbuhan keilmuannya, wawasan berpikir, sikap terhadap pekerjaan dan keterampilannya dalam pelaksanaan tugas sehari-hari hingga produktivitas kerja dapat ditingkatkan.

Kinerja guru berkisar pada beberapa aspek yaitu : (1) perumusan tujuan-tujuan pengajaran yang mencakup tiga aspek pokok, yaitu aspek kognitif, aspek afektif, dan aspek psikomotorik dengan strategi dan metode tertentu. (2) penyusunan bahan dan alat pelajaran yang akan digunakan. Hal ini mengacu kepada pokok-pokok bahasan yang termuat dalam kurikulum pegangan. (3) pembahasan metodemetode yang digunakan dalam proses belajar megajar. (4) penyusunan alat evaluasi dan penggunaannya dalam keseluruhan proses belajar mengajar. (5) pelaksanaan bimbingan belajar baik secara kelompok maupun yang bersifat perorangan terhadap siswa-siswa.

Semua aspek tersebut dapat dilaksanakan oleh guru apabila kepala sekolah mempunyai kemampuan untuk mengarahkan, membimbing dan mengawasi guru dalam melaksanan aspek-aspek tersebut.

\section{KESIMPULAN}

Berdasarkan hasil analisis dan pembahasan pada bab sebelumnya, maka dapat ditarik kesimpulan sebagai berikut

1. Kepemimpinan manajerial Kepala Sekolah SMA Negeri Kabupaten Bulukumba berada pada kategori sedang, artinya dari hasil analisis 
distribusi frekuensi menunjukkan bahwa tanggapan guru terhadapat kepemimpinan manajerial kepala sekolah cenderung sedang

2. Kinerja Guru SMA Negeri di Kabupaten Bulukumba pada responden kepala sekolah, wakil kepala sekolah dan komite sekolah berada pada kategori cenderung kuat sedangkan pada responden siswa berada pada kategori kuat

3. Kepemimpinan manajerial kepala sekolah berhubungan secara signifikan yaitu berada pada kategori kuat dengan kinerja Guru SMA Negeri Kabupaten Bulukumba.

\section{DAFTAR PUSTAKA}

Ali, S.N.M., Harun, C,Z., Djailani, A.R. 2015. "Gaya Kepemimpinan Kepala Sekolah dalam Meningkatkan Kinerja Guru pada SD Negeri Lambaro Angan. Jurnal Administrasi Pendidikan3(2):116127 ISSN 2302-0156

Arikunto, S. (2003). Dasar Evaluasi Pendidikan.Jakarta: Rineka Cipta.

Arnold, J. Hugh and Fiedman, C. Daniel. 1996. Organisation Behavior, New York : Mc. Graw-Hill Book Company.

Arsyad, A.2001. Manejemen Pendidikan Bahasa Arab : Sebuah tinjauan Teologis, Kultural dan psikodinamik. Pidato penerimaan Jabatan Guru Besar Bahasa Tetap Pendidikan Bahasa Arab dan Ilmu Manejemen Fakultas Tarbiyah IAIN Makassar: IAIN Alaudin.

Burhanuddin. 1994. Analisis Administrasi Manajemen
Kepemimpinan Pendidikan. Jakarta: Bumi Aksara.

Fatta. 1999. Landasan Manejemen Pendidikan Remaja. Bandung : Rosda Karya.

Frimaiyulis. 2013. "Hubungan Gaya Kepemimpinan Kepala Sekolah dengan Kinerja Guru di SMK Negeri 2 Pariaman." Jurnal Administrasi Pendidikan: Bahana Manajemen Pendidikan 1(1):34946

Gibson, James L, et. Al. 1997. Organisasi, Perilaku, Struktur dan Proses. Jakarta:Bumiputra Aksara.

Gusman, H.E. 2014. "Hubungan Gaya Kepemimpinan Kepala Sekolah dengan Kinerja Guru di SMP Negeri Kecamatan Palembayan Kabupaten Agam." Jurnal Administrasi Pendidikan: Bahana Manajemen Pendidikan 2 (1):293831

Hasibuan, S.P. Melayu. 2001. Manejemen Dasar, Pengertian, dan makalah. Edisi Revisi. Jakarta: PT.Bumi Aksara.

Jamali, A dan Prasojo, L.D. 2013. "Pengaruh Kompetensi Manajerial Kepala Sekolah, Lingkungan, Motivasi Guru, terhadap Prestasi Siswa SMA Muhammadiyah Kota Yogyakarta." Jurnal Akuntabilitas Manajemen Pendidikan 1(1):8-21

Karang, A.W.N., Yudana, M., Natajaya, N. 2013. Studi Hubungan Antara Kepemimpinan Kepala Sekolah, Kompetensi Profesional, dan Motivasi Kerja Guru Terhadap Kinerja Guru SMP Negeri 1 Bangli. e-Journal Program Pascasarjana Universitas Pendidikan Ganesha Volume 4 Tahun 2013 
Mangkunegara. 2000. Kinerja Pegawai Negeri Depdiknas Jakarta.

Mulyasa, E. 2004. Menjadi Kepala Sekolah Profesional. Bandung: PT. Remaja Rosdakarya.

Moedjiarto, 2002. Karakteristik Sekolah Unggul. Bandung: Duta Graha Pustaka.

Rosyadi, Y.I dan Pardjono. 2015.’Peran

Kepala Sekolah Sebagai Manajer Dalam Meningkatkan Mutu Pendidikan di SMP 1 Cilawu Garut."Jurnal Akuntabilitas Manajemen Pendidikan 3 (1):124133.

Siagian, SP.1996. Teori dan Praktek Kepemimpinan. Jakarta : Rineka Cipta.

Sugiono. 2003. Metode Penelitian Administrasi. Alfabeta Bandung.

Sujuk . 1990. Kepemimpinan Manejerial. Depdikbud Jakarta

Syarifuddin, 2006. Hubungan antara strategi Manejemen konplik Organisasi oleh Kepala Sekolah, Iklim Sekolah, insentif guru, dan , Motivasi Berprestasi Guru dengan Kinerja Guru sekolah menengah Kejuruan Negeri di Sulawesi Selatan,. Disertasi Tidak diPublikasikan, Malang:Program Pascasarjana Universitas Negeri Malang.

Tilaar, H.A.R. 2002. Membenahi Pendidikan Nasional. Jakarta: PT Rineka Cipta.

Tiro, A. 2005. Dasar-Dasar Statistika. Badan Penerbit Universitas Makassar.

Wahjosumidjo. 2002. Kepemimpinan Kepala Sekolah. Jakarta: PT.Raja Grapindo Persada.
Wibowo, P., Suntoro, I., dan Sumadi. 2013. 'Hubungan Kompetensi Manajerial Kepala Sekolah dan MotivasiBerprestasi Dengan Kinerja Guru Di SD Gugus IV Kemiling Permai, BandarLampung." Jurnal Manajemen Mutu Pendidikan Vol 1 , No 3 
\begin{tabular}{l|l} 
Jurnal Noken 2(2)29-42 & 2017 \\
\hline
\end{tabular} 